Acta medico-historica Rigensia (2020) XIII: 93-103

doi:10.25143/amhr.2020.XIII.06

II. AKADĒMISKĀ UN MUZEJU DZĪVE

Marika Garnizone, Juris Salaks

\title{
The International Society for the History of Medicine Begins the Celebration of Its 100th Anniversary in Latvia
}

In August 2020, Riga became the world's capital of the history of medicine, hosting the 47th Congress of the International Society for the History of Medicine (ISHM). The Congress was organised by the Latvian Society for the History of Medicine in cooperation with Rīga Stradiņš University and Pauls Stradiņš Museum of the History of Medicine.

\section{The Beginning of the ISHM}

National societies of the history of medicine began to form at the begining of the 20th century: in 1901 in Germany, in 1902 in France, in 1910 in Italy, in 1912 in the United Kingdom, and in 1918 in Belgium. Initially, the societies organised their meetings within the framework of congresses of medical professionals - the first section dedicated to the history of medicine took place in 1913 in London, at the 27th International Medical Congress.

The International Society for the History of Medicine began to form soon after the end of World War I. The establishment of the Society was important for scientists (historians and doctors) from different countries to restore the bonds of science that had been torn by the war. ${ }^{1}$

As the ranks of medical historians grew, a separate conference dedicated to the history of medicine was convened in Antwerp in $1920-$ the First Congress of the History of the Art of Treatment, bringing together 191 participants from 10 countries. This event marked the beginning of the International Society for the History of Medicine.

1 N. N. Kolotilova. "Otkrytie 47 Kongresa Mezhdunarodnovo obshchestva ustorikov mediciny.” Zhizn Zemli, 2020, 42 (3: 379-380. 
Since 1920, 46 ISHM congresses have taken place, and today the Society unites 260 medical historians from five continents. The Society is multidisciplinary, however, historically most of the members are medical professionals from various fields who are interested in the historical research of their profession.

\section{Traditions of the History of Medicine in Latvia}

Who could have imagined in 1920 that the centenary congress of the International Society for the History of Medicine would take place in Latvia, a country that had just appeared on the map of Europe at that time? However, this is not a coincidence, but rather well-deserved recognition for the tradition of the history of medicine formed and carefully nurtured by several generations of Latvian physicians. Doctor Orthopaedist Izidors Brensons (1854-1928), Professor Pēteris Sniķers (1875-1944), Jēkabs Alksnis (1870-1957), Pauls Stradiņ̌̌ (1896-1958), Kārlis Ēriks Arons (1903-2005), Arnis Vīksna (1942-2018), Professor Jānis Stradiṇš (19332019) have special merits in this area, along with many others who have nurtured the field of Latvian and world medical history. ${ }^{2}$

In addition, the history of Latvian medicine stands out among other countries not only for academic research, but also for the ability to preserve the material heritage of medicine and the ability to interest the general public in the history of medicine. The fruit of the active life of Pauls Stradiñ - the Museum of the History of Medicine - is one of the three most remarkable medical museums in the world and is known to every medical historian (at least remotely), making the name of Latvia and the founder of the museum known around the world. Also, since 1920, the Anatomy Museum founded by Swedish Professor of Anatomy Gaston Viktor Bakman (1883-1964) has been located in Riga, in the Anatomical Theatre on Kronvalda Boulevard. It has served as a training museum for all generations of Latvian physicians for almost a hundred years. In 1987, the collection was taken over by the Pauls Stradinšs Museum of the History of Medicine. On 1 July 2017, the anatomical collection was transferred to Rìga Stradiņš University (RSU) to ensure its preservation and more active use in accordance with modern requirements. At the end of 2020,

2 J. Salaks, I. Lībiete. "Latvija - pasaules medicīnas vēstures epicentrs 2020. gadā." Latvijas Ārsts, 2019, maijs-jūnijs, 118-119. 
the contemporary RSU Anatomy Museum will open its doors to the general public. It will be a place not only for getting acquainted with historical anatomical preparations, but also a space for RSU students' classes in the study programme on the history of medicine and life sciences, various social and cultural activities for residents and guests of Riga of different ages. ${ }^{3}$

In 1953, Professor Pauls Stradiňš founded the Latvian Scientific Society for the History of Medicine. There is no evidence that Pauls Stradiņš was a member of the International Society for the History of Medicine or attended its congresses. Most likely, he did not have time for this in his active medical practice, nor was it facilitated by the socio-political situation under the oppression of the occupation regimes.

\section{The Path of Latvian Society for the History of Medicine to the Organisation of the ISHM Congress}

Only in 1991 did Latvian medical historians have the opportunity to become fully-fledged members of the International Society for the History of Medicine and participate in its congresses. ${ }^{4}$ In 2014, the congress was organised in a post-Soviet country for the first time - Georgia. It inspired Latvian delegates and gave them an ambitious idea, and in 2016, during the Buenos Aires Congress, Riga was nominated as the venue for the 2020 Congress. Thanks to the support of Rīga Stradiņš University, Pauls Stradiņš Museum of the History of Medicine and other organisations and sponsors, this idea became reality - at the 2017 ISHM office meeting in Beijing, beating Paris and Moscow in a fierce competition, Riga was confirmed as the venue for the ISHM Centennial Congress.

In 2018, in Lisbon, the Rector of Rīga Stradiņš University, Professor Aigars Pētersons, from the high podium of the 46th Congress, invited the participants to attend the 47th Congress of the International Society for the History of Medicine in Riga in 2020 and officially opened the congress website www.ishm2020.com. ${ }^{5}$

3 “RSU Anatomy museum" accessed on 11 October 2020, https://www.rsu.lv/en/aboutus/anatomy-museum/history

4 Acta medico-historica Rigensia (Rīga, 2016), X: 235-248. doi:10.25143/ amhr.2016.X.12

5 "Riga to host the Centenary Congress of the International Society for the History of Medicine," http://ishm2020.rsu.lv/news/riga-host-centenary-congress-internationalsociety-history-medicine 


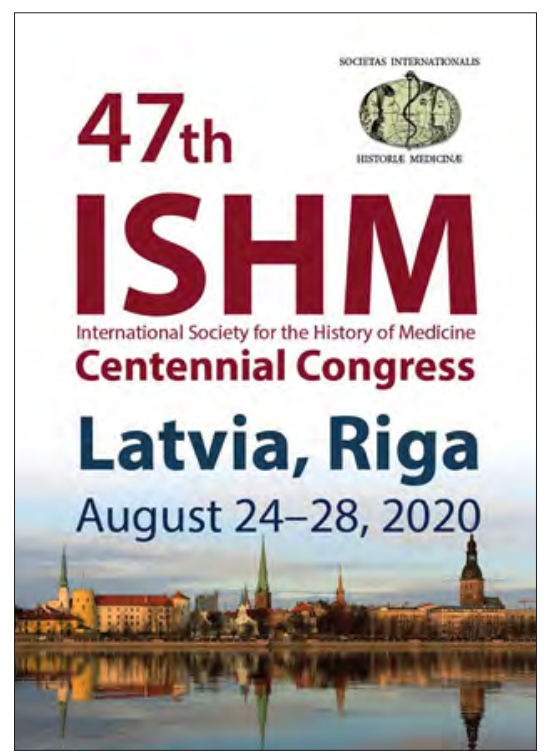

Early public announcement of the 47th ISHM Congress in Riga, Latvia. It was first made during the 9th ISHM conference in Beijing in September 2017

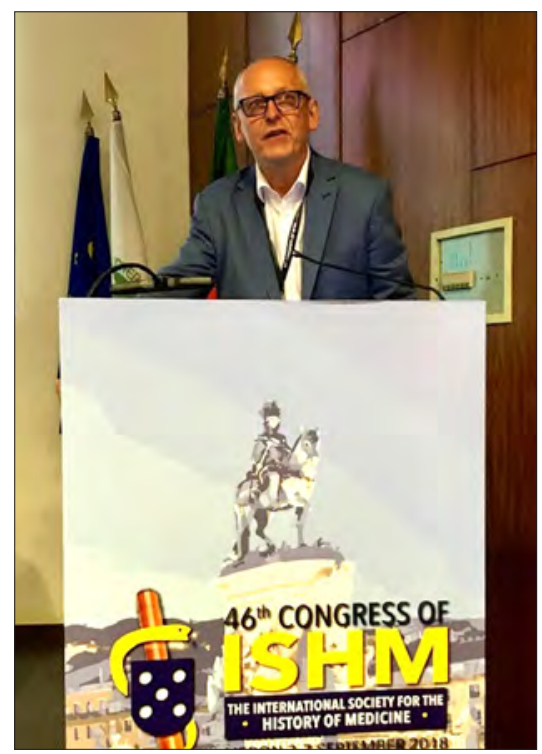

In September 2018, during the 46th ISHM Congress in Lisbon, the Rector of Rīga Stradiņ̌̌ University, Professor

Aigars Petersons, is inviting the attendees to attend the next ISHM Congress in Riga in 2020, and launching the Congress website (Photo by Juris Salaks)

The work was commenced by the congress organising committee: Congress Patron Dr. med. Valdis Zatlers (His Excellency, former President of the Republic of Latvia), Congress Honorary President Professor Dr. habil. med. Aigars Pētersons (Rector of Rīga Stradiņš University), Congress President Professor, Dr. med. Juris Salaks (Director of the Institute of the History of Medicine, Rīga Stradiņš University), General Secretary Assist. Professor, Dr. med. Ieva Lībiete (Institute of the History of Medicine, Rīga Stradiņš University), Congress vice-presidents Professor Pēteris Stradiņš (Rīga Stradiņš University), Kaspars Vanags (director, Pauls Stradiņš Museum for the History of Medicine). ${ }^{6}$

6 “47th ISHM Congress Committee,” http://ishm2020.rsu.1v/committees/47th-ishm-congress-committee 


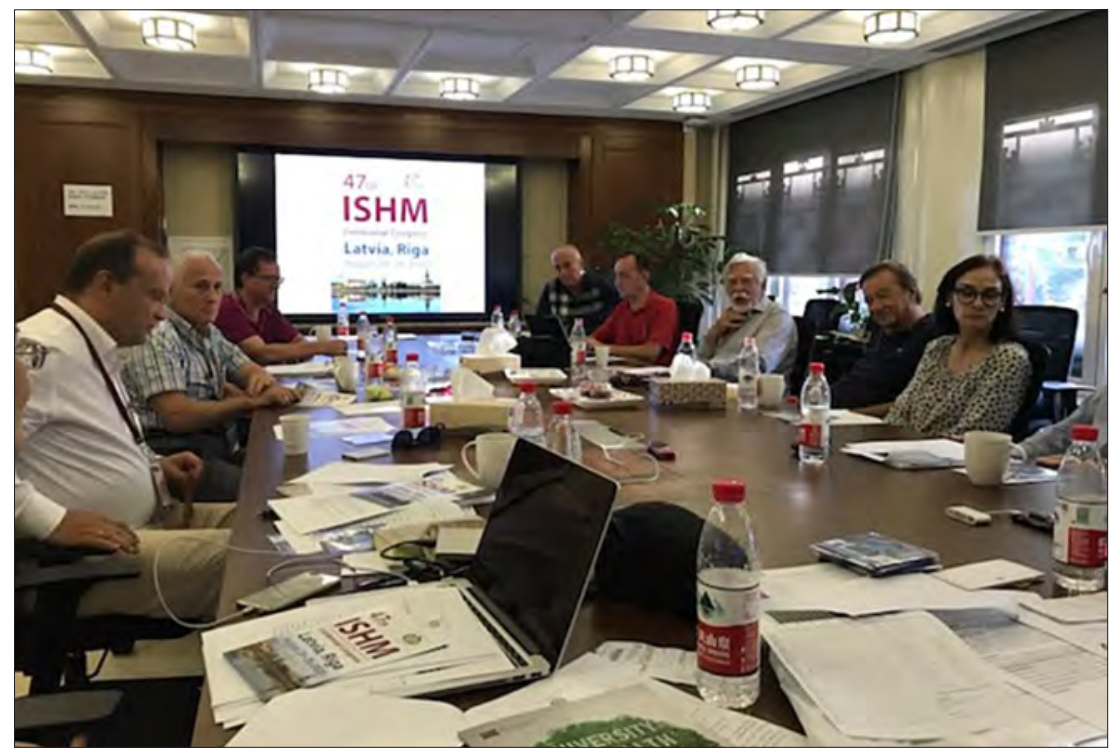

On 6 September 2017, during the Executive Committee of the ISHM meeting in Beijing, Riga was approved as the venue for the 47th ISHM Centenary Congress

(Photo by Juris Salaks)

The planning of the Congress included an ambitious opening in the RSU Great Hall, work in plenary sessions, panel discussions, oral presentations and poster sections, as well as an extensive socio-educational programme and a student summer school. An extended meeting of the organising committee with supporters, sponsors and foreign ambassadors took place on 4 March 2020 at the Marriott Hotel in Riga.

At the beginning of the year, there were concerns about the sudden global changes related to the spread of COVID-19 infection and the epidemiological precautions taken to control it. It also affected Latvia, and a national state of emergency was declared and the borders were closed on 12 March 2020. Congress organisers had to decide how to proceed. The health and safety of the delegates, speakers and sponsors was the most important priority. After carefully evaluating the development of the Covid-19 pandemic it was decided to ask the ISHM executive committee to change the dates for the 47th ISHM Congress in Riga to 23-27 August 2021. It was approved. 
Professor Dana Baran, General secretary of the ISHM stated:

"Even if in 1920, ISHM was not yet born but an independent congress of history of medicine \& pharmacy was going on, a century later - because of the pandemic - we'll write a historical page, even if electronically speaking, starting our Centenary jamboree and a scientific offer possibly lasting a year, through different approaches and links." 7

These events have drawn medical historians' interest in pandemics in the past and it was decided that a session dedicated to the history of epidemics and particularly to pandemics should be added to the themes of the ISHM Congress.

\section{Opening of the 47th ISHM Congress}

Nevertheless, as planned, on 24 August 2020 in an improvised studio in Rīga Stradiņš University led by the President of the Congress, Professor Juris Salaks and Congress General Secretary Assistant Professor Ieva Libiete, the 47th Anniversary Congress of the ISHM was opened virtually. There was a 90 minute broadcast of pre-recorded official congress opening speeches by the Rector of RSU, Professor Aigars Pētersons, cardiosurgeon, RSU Professor Pēteris Stradiņš and Director of the Pauls Stradiņš Museum of the History of Medicine Kaspars Vanags, Zoom webinar online greetings from the National delegates from different continents, as well as impressive and beautiful live organ and piano music in between. The congress was greeted in special video speeches. ${ }^{8}$

The congress opening speeches followed, starting with Carlos Viesca Treviño, President of the Society (Mexico), then General Secretary of the Society, Professor Dana Baran (Romania) and the President of the satellite conference "Anatomy \& Beyond" Pascale Pollier (Belgium).

Carlos Viesca Treviño said:

"I am happy to open this congress. It is important to recall that now starts the celebration of the 100 years of the existence of our society.

7 D. Baran. "ISHM Activity," email message to Salaks J. on 29.04.2020.

8 L. Borghi. Newsletter. International Society for the History of Medicine. Autumn 2020, pp. 1-3. 
Our society was born in the years immediately after World War I and in agitated times, with the rebuilding of the states of Europe, America, international relationships etc. And also, with a growing conscience about what signifies history regarding our identity as humans, our identity as social working people, our identity as medical people, as well as the importance of looking to the future. This question started 100 years ago and now it is reborn among us. It is important to think about what signifies that we are living for the history of humanity, but also for the history of medicine. The important thing for us, is that which signifies health - new discoveries, new problems, new viruses, new illnesses, but also, always people working for the health of humanity. This centenary opens a hundred years more to the future for us."

The Congress was also addressed by several national delegates via Zoom webinar.

During the virtual opening, Professor Jean-Pierre Tricot, national delegate from Belgium and grandson of the founding President of the ISHM said:

"I'm very glad that in these circumstances Professor Salaks accepted the challenge to organise the congress in his country. The first Congress was organised in Antwerp after World War I. Now we are in quite a different kind of war against the corona virus - a new microbiological war. Since ancient times we have been confronted with different forms of plague and fever, and we have always been able to eliminate them. We are confident that the same thing will happen now. It was and it is always very interesting to study the health problems of the past so we can at least learn about the best way to eliminate them. When we consulted the proceedings of all the past congresses, we realised that their contribution to science is far from negligible. This allows us to continue in the same vein. I'm sure that the Congress in Riga will be an important Congress, and play an important role in realising this goal."9

9 "Recording of the Virtual Opening of the 47th Congress of the ISHM available," http://ishm2020.rsu.1v/news/recording-virtual-opening-47-congress-ishm-available 

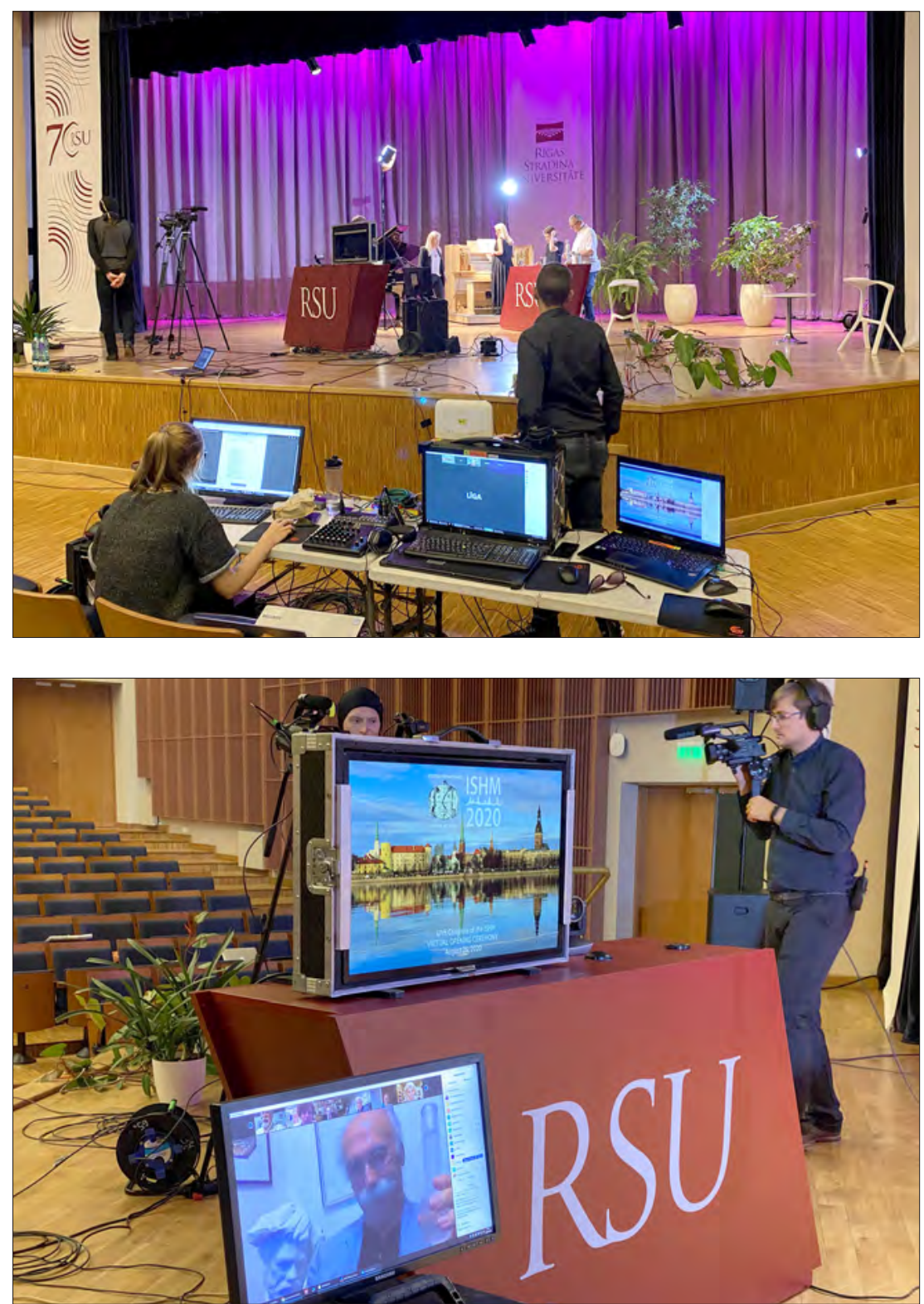

The virtual opening of the 47th ISHM Centenary Congress took place on 24 August 2020 in an improvised studio in the Great Hall of Rīga Stradin̄š University (Photo by Edijs Šauers) 


\section{Content of the Congress}

The active work of the congress organising committee also continues after the virtual opening in August 2020. World-renowned experts in the history of medicine are invited to give lectures in plenary sessions. The invited lecturers Nils Hannson (Sweden / Germany), Alexander Lukas Bieri (Switzerland), Jacalyn Duffin (Canada) and Dan Healey (United Kingdom), as well as moderators Theo Dirix (Belgium) and Florian Steger (Germany), have reaffirmed their participation in the Congress.

Section meetings of the Congress will be held on the following topics:

- ISHM. Towards 100;

- Medicine around the Baltic Sea region;

- History of Medicine: Beyond the Borders and Behind the Curtains;

- The Visual and Material Culture of Medicine;

- Two Sides of the Nobel Prize;

- Medical Collections and Collectors;

- Hippocratic Traditions in Eastern and Western Medicine;

- Physicians Outside Medicine;

- History of Medical Education and Medical Schools;

- New Research Technologies for the History of Medicine;

- Architecture for Medicine;

- Medical Women;

- Great Remedies;

- Environmental Disasters in the History of Medicine;

- Pandemics and Epidemics in the History of Medicine.

Professor A. Musajo Somma is a board member of the ISHM and has been actively engaged in organising the 47th Congress of the ISHM in Riga. In 2019, Professor Musajo was awarded the Pauls Stradinš Prize for his contribution to strengthening the role of Latvia, the Latvian Association of Medical Historians, Rīga Stradiņš University and Pauls Stradiņš Museum of the History of Medicine among medical historians on an international scale. The award will be presented to the professor during the special event of the congress and he will deliver an academic speech. ${ }^{10}$

For the first time in ISHM history: 1st Summer School on the history of medicine, will be organised by the Institute of the History of Medicine

10 “Preliminary Programme," http://ishm2020.rsu.lv/program/preliminary-program 
of Rīga Stradiņš University and hosted by Pauls Stradiņš Museum of the History of Medicine. Junior scholars and students of all backgrounds interested in the history of medicine are invited to present their ongoing work, receive feedback, establish valuable academic contacts within ISHM and explore the medical heritage of the Baltic states. ${ }^{11}$

As an interdisciplinary Congress it will include a satellite conference "Anatomy \& Beyond" and an exhibition. Pascale Pollier, the organiser of the satellite congress said in the virtual opening of the Congress: "We had the idea of holding a conference "Anatomy and beyond" to talk about the future of medicine and also the future of our human bodies, and how human bodies will change as we venture into space or how it will affect our human bodies."

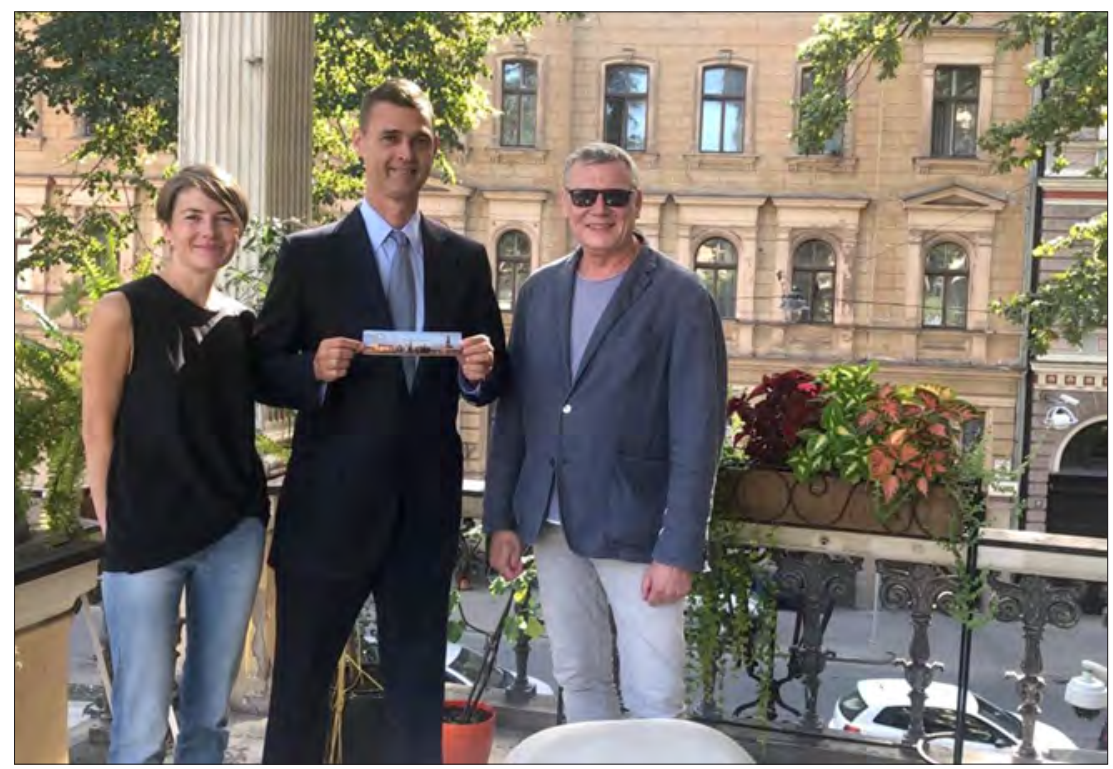

Meeting Sebastiano Fulci, the Ambassador of Italy in Latvia, on cooperation for the 47th ISHM Congress in Riga, August 2019.

From left - Ieva Lỉbiete, General Secretary of the Congress, from right - Professor Juris Salaks, President of the Congress (Photo by Līga Hartpenga)

11 “1st ISHM Summer School on the history of medicine," http://ishm2020.rsu.lv/ news/1st-ishm-summer-school-history-medicine 
The scientific and social programme of the Congress is being adjusted, and accompanying events are being coordinated. A new session, "Epidemics and pandemics" has been included on the list of topics of the Congress. The first online lectures on the topic "Politicised medicine" are already available on the Congress webpage. They include a lecture on Closed Venereology Wards in the German Democratic Republic (GDR) by Professor Dr Florian Steger (Institute of the History, Philosophy and Ethics of Medicine, Ulm University, Germany) and a lecture by Dr. Marcin Orzechowski (Institute of the History, Philosophy and Ethics of Medicine Ulm University, Germany) on Politicised Medicine in the Polish People's Republic (PPR): Policy approaches towards combatting venereal diseases, 1945-1989. ${ }^{12}$

As registration for participation on the congress website is extended until 8 March 2021 due to new circumstances, there is still time to become a member of the Latvian or even the International Society of the History of Medicine and register for participation in the Congress with a report or as a listener in various fields of the history of medicine. The extensive scientific and social programme of the Congress will even pleasantly surprise those physicians who are not closely following the developments in the history of medicine in Latvia and around the world on a daily basis. Let's explore the past to understand the present and build a better future! 13

Let's support the traditions of the Latvian history of medicine nurtured by many doctors, and meet on 23-27 August 2021 at the 47th Congress of the International Society of the History of Medicine in Riga!

Marika Garnizone

RSU Medicīnas vēstures institūts, Latvija /

$R S U$ Institute of the History of Medicine, Latvia

Juris Salaks

Profesors, RSU Medicīnas vēstures institūts, Latvija /

RSU Institute of the History of Medicine, Latvia

12 "Online Lectures on "Politicised Medicine"," http://ishm2020.rsu.lv/news/line-lectures-politicized-medicine

13 “Abstract Submission," http://ishm2020.rsu.lv/abstract-submission 